\title{
Wheat sample affects growth performance and the apparent metabolisable energy value for broiler chickens
}

by Azhar, M.R., Rose, S.P., Mackenzie, A.M., Mansbridge, S.C., Bedford, M.R., Lovegrove, A. and Pirgozliev, V.R.

Copyright, Publisher and Additional Information: This is the authors' accepted manuscript. The final published version (version of record) is available online via Taylor \& Francis

Please refer to any applicable terms of use of the publisher.

DOI: https://doi.org/10.1080/00071668.2019.1605152

Harper Adams University 
1 Wheat sample affects growth performance and the apparent metabolisable energy value

2 for broiler chickens

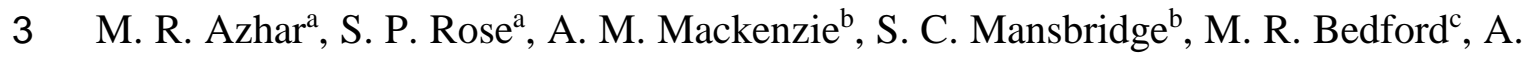

4 Lovegrove $^{\mathrm{d}}$, V.R. Pirgozliev ${ }^{\mathrm{a}, *}$

5 aThe National Institute of Poultry Husbandry, Harper Adams University, Newport,

6 Shropshire, UK

$7 \quad$ bepartment of Animal Production, Welfare and Veterinary Sciences, Harper Adams

8 University, Newport, Shropshire, UK

$9 \quad{ }^{\mathrm{c}} \mathrm{AB}$ Vista, Marlborough, UK

$10 \quad{ }^{\mathrm{d}}$ Rothamsted Research, Harpenden, UK

11 *Corresponding author: V.R. Pirgozliev

12 Email: vpirgozliev@ harper-adams.ac.uk

13 Tel: $+44(0) 1952815408$ 


\section{ABSTRACT}

15 1. The aim of this study was to examine chemical composition, quality 16 characteristics, apparent metabolisable energy (AME) and nutrient utilisation 17 of wheat samples currently available to the UK poultry industry and their effect 18 on broiler growth performance.

2. Seventeen current UK wheat samples were used to formulate 17 diets, all of which included $670 \mathrm{~g} / \mathrm{kg}$ of each wheat sample and $330 \mathrm{~g} / \mathrm{kg}$ of a balancer feed. Eight hundred (800), day old male Ross 308 broilers were allocated randomly to 160 raised floor pens. Each diet was replicated eight times, fed ad libitum from 0 to $21 \mathrm{~d}$ age in a randomised complete block design. Excreta were quantitatively collected during the last three days for AME determination.

3. The content of protein, ash and gross energy (GE) ranged from 97 to $143 \mathrm{~g} / \mathrm{kg}$ DM, 12.8 to $19.6 \mathrm{~g} / \mathrm{kg} \mathrm{DM}$ and 17.81 to $18.24 \mathrm{MJ} / \mathrm{kg} \mathrm{DM}$, respectively. The amount of starch and total non-starch polysaccharides (NSP) ranged from 671 to 728 and 80.1 to $98.2 \mathrm{~g} / \mathrm{kg} \mathrm{DM}$, respectively. The quality characteristics of wheat samples were in the expected range.

4. There were differences $(P<0.05)$ in AME and AMEn of wheat samples. The AME of the wheat had a maximum range of $1.13 \mathrm{MJ} / \mathrm{kg} \mathrm{DM}$ between samples. Dry matter retention (DMR) and fat digestibility (FD) were significantly different $(P<0.05)$ between wheat samples.

5. The daily feed intake (FI) and weight gain (WG) of broilers fed two wheat samples were significantly $(P<0.05)$ lower as compared to other samples and 
their low FI and WG were not related to their chemical composition and quality characteristics.

6. The ash content of wheat samples was negatively associated with AMEn ( $\mathrm{r}=$ $-0.489, P<0.05)$. The coefficient of FD was positively related to AMEn $(\mathrm{r}=$ $0.552, P<0.05)$

7. Chemical composition and quality characteristics of the wheat did not relate ( $P$ $>0.05)$ to FI and WG of broilers. There was also no relationship between growth performance of broilers and AMEn of the wheat samples.

44 KEYWORDS: wheat, chickens, metabolisable energy, feed intake, weight gain

\section{Introduction}

47 The main goal of efficient broiler production is to achieve good growth performance

48 with high feed efficiency. Wheat, specifically grown for feed and also that in excess

49 of milling processes (bread, biscuits, cakes), is the main cereal used in commercial

50 broiler diet formulations in the UK and northern Europe. High yield and low cost

51 available energy (price/MJ of metabolisable energy) make wheat one of the most

52 economically competitive cereals in poultry feed, accounting for up to $70 \%$ of the

53 metabolisable energy (ME) and $35 \%$ of the protein requirements of commercial

54 broilers (Gutierrez del Alamo et al. 2008b). There is, however, considerable variation

55 in ME content of wheat samples, with ranges between $8.5-16.4 \mathrm{MJ} / \mathrm{kg} \mathrm{DM}(\mathrm{McNab}$

56 1991; Wiseman 2000; Ravindran and Amerah 2009). This large variation in ME

57 content of wheat makes it challenging for nutritionists to predict the feeding value of

58 wheat for broilers. 
59 The majority of the work on UK wheat samples and their effect on apparent

60 metabolisable energy (AME) and broiler growth performance was conducted $15-20$

61 years ago (Waldron 1997; McCracken and Quintin 2000; Wiseman 2000; Rose et al.

62 2001; Pirgozliev et al. 2003). These studies have not demonstrated conclusive

63 information on how chemical composition and quality characteristics of wheat are

64 related to AME and growth performance of broilers, however, they have indicated that

65 differences in AME exist (Waldron 1997; Scott et al. 1998; Steenfeldt 2001). Starch

66 is the main energy yielding component of wheat, but inconsistent relationship between

67 starch and AME of wheat was reported (Svihus and Gullord 2002; McCracken et al.

68 2002). Instead of starch contents, digestibility of starch in wheat based diets was

69 associated with AME (Wiseman et al. 2000; Carre et al. 2005).

70 Broiler response to wheat based diets in many previous studies have been due to

71 differences in protein contents of wheat samples (Steenfeldt 2001; Pirgozliev et al.

72 2003; Hetland et al. 2004). The protein content of the wheat is variable, ranges between

$738-17 \%$ depending on variety and the growing condition (Scott et al. 1998; Wiseman

74 2000; McCracken et al. 2002). Protein content of wheat is inversely related to starch

75 content (Svihus and Gullord 2002; Ravindran and Amerah 2009). Therefore, there is

76 a need to consider the factors other than protein such as starch, non-starch

77 polysaccharides (NSP) and investigate their relationship with broiler growth

78 performance and ME. Current wheat cultivars have undergone numerous changes in

79 chemical composition, quality and yield. High yield wheat varieties with better

80 resistance to diseases have been produced (AHDB 2015). Wheat genotype, soil

81 composition, seasonal changes, crop husbandry and agronomic factors have changed

82 UK wheat significantly in the last two decades. Wheat varieties with low

83 arabinoxylans are now available, which have the benefit of conferring a low ileal 
84 digesta viscosity for broilers resulting in improvement in growth performance of

85 broilers (Choct and Annison 1992a, b; Pirgozliev et al. 2015).

86 The objectives of this study were (a) to define the chemical composition, quality

87 characteristics of current UK grown wheat samples, (b) to investigate the differences

88 in AME and growth performance of broilers (c) to determine if differences were

89 related to chemical composition, quality characteristics and nutrient utilisation of the

90 wheat.

$91 \quad$ Materials and methods

\section{Wheat samples}

93 Seventeen UK wheat samples harvested in the year 2015, sourced from Klien

94 Wanzlebener Saatzucht (KWS UK Ltd), grown on four different sites in the UK

95 (Yorkshire, Nottinghamshire, Lincolnshire and Cambridge) were used in this study

96 (Table 1). The samples were specifically grown for this study and were among

97 currently available UK wheat samples (AHDB recommended list 2016/2017). Wheat

98 samples comprised of hard feed wheat, soft feed wheat, hard milling wheat and soft

99 milling wheat. Hard milling varieties (Lili and Trinity) are used for bread making

100 markets, while soft varieties (Barrel and Basset) are suitable for cakes and biscuits.

101 Feed wheat varieties are high yield varieties, specifically grown for animal feed

102 industry. Wheat samples were received in $25 \mathrm{~kg}$ bags. Each sample was mixed

103 homogenously from 10 minutes, and random samples were collected for analyses. The

104 collected samples were milled to pass through a $0.75 \mathrm{~mm}$ screen using Retsch ZM 200

105 (Retsch GmbH, Haan, Germany). All analyses were performed in duplicates. 
106

107

108

109 determined by dry combustion method (AOAC, 2012; 990.03) using a LECO FP-528

110 N (Leco Corp., St. Joseph, MI, USA). Fat (as ether extract) was extracted with 40-60

$111{ }^{0} \mathrm{C}$ petroleum ether by ether extraction method (AOAC, 2012; 920.39) using a Soxtec

112 system (Foss UK Ltd, Warrington, UK). Gross energy (GE) was determined in a bomb

113 calorimeter (model 6200; Parr Instrument Co., Moline, IL, USA). Crude ash was

114 determined in a muffle furnace at $550{ }^{\circ} \mathrm{C}$ for $4 \mathrm{~h}(\mathrm{AOAC}, 2012 ; 942.05)$.

\section{Carbohydrate analysis}

116 Total starch (TS) was analysed following the method of Englyst et al. (2000). Wheat 117 non-starch polysaccharide fraction (NSP) was determined by the method of Englyst et 118 al. (1994), by starch dispersion and then hydrolysed enzymatically. The NSP is 119 isolated by precipitation in $80 \%$ ethanol, then hydrolysed by sulphuric acid and the 120 released sugars were measured by gas chromatography as their alditol acetate 121 derivatives.

\section{Grain quality analysis}

123 Hagberg falling number (HFN) was determined by HFN apparatus model 1400 124 (Falling Number AB, Stockholm, Sweden) (AOAC 976.13). Specific weight (SW) $125 \mathrm{~kg} /$ hectolitre (hl) was determined by Chondrometer (Farm Tec, Yorkshire, UK). 126 Endosperm Hardness (EH) was determined using a Single Kernel Characterisation 127 System (SKCS 4100, Perton Instrument, Hagersten, Sweden). Three hundred (300) 128 kernels of cleaned wheat were assessed for each sample. Thousand grain weights 129 (TGW) of wheat samples was determined by weighing 1000 randomly selected grains. 130 Dynamic water extract viscosity (DV) was determined by cup and cone viscometer 
131 (model DV-II + LV, Brookfield, Stoughton, MA, USA) as described by Pirgozliev et

132 al. (2003). The Wheat sample (2 $\mathrm{g})$ was soaked in distilled water (4 $\mathrm{ml})$ in a glass tube

133 in water bath at $40^{\circ} \mathrm{C}$ for 30 minutes. Then each tube was centrifuged at $10000 \mathrm{x} \mathrm{g}$ for

1342 minutes. The tubes were left for 15 minutes at room temperature and $0.5 \mathrm{ml}$ aliquot

135 in duplicates was taken for viscosity measurement. The viscosity of supernatant was

136 measured in centipoise (cP) by viscometer. Kinematic water extracted viscosity (KV)

137 of wheat samples was determined using an automated viscometer (AVS 370 SCHOTT

138 Instruments, Analytics, Germany) fitted with an Ostwald capillary tube (Saulnier et 139 al., 1995).

\section{Diet preparation}

141 Each wheat sample was milled to pass through a $3 \mathrm{~mm}$ screen and mixed with a

142 balancer feed (Target Feeds Ltd, Whitchurch, UK). A balancer feed was formulated

143 including major ingredients of $521.3 \mathrm{~g} / \mathrm{kg}$ soybean meal (SBM), $299.2 \mathrm{~g} / \mathrm{kg}$ of full-fat

144 soymeal, $60.5 \mathrm{~g} / \mathrm{kg}$ soya oil, and contained $374.5 \mathrm{~g} / \mathrm{kg} \mathrm{CP}$ and $12.45 \mathrm{MJ} / \mathrm{kg}$ AME

145 (Table 2). Hammer mill was cleaned after milling each wheat sample to avoid any

146 cross contamination of different samples. Seventeen diets were prepared by mixing

$147645 \mathrm{~g} / \mathrm{kg}$ of each of the seventeen experimental wheat samples with $330 \mathrm{~g} / \mathrm{kg}$ of a

148 balancer feed. Diets were made iso-nitrogenous by adding wheat protein isolate (WPI)

$149(25 \mathrm{~g} / \mathrm{kg})$ to each wheat sample by substituting wheat with WPI. The additional

150 quantity of WPI to be added was estimated on analysed protein value of each wheat

151 sample on as fed basis. A relatively small contribution of energy provided by

152 additional protein was taken into consideration during AME determination of each

153 diet. The determined AME of the diet in this study was the AME of the mixture (wheat 154 plus WPI). 
155 The AME was not determined on balancer diet because it would have inappropriate 156 supply of nutrients for broilers. Three additional diets $(18,19,20)$ were formulated by 157 mixing 470, 570 and $770 \mathrm{~g} / \mathrm{kg}$ of one of the wheats (sample 8) with 530, 430 and 230

$158 \mathrm{~g} / \mathrm{kg}$ of balancer feed, respectively for AME determination of balancer diet by slope 159 ratio method (Finney 1978). The nutritional profile of each additional diet was closed 160 to nutrient specification of broilers. AME of balancer diet was then predicted by 161 regression analysis of diet $8,18,19$ and 20. Sample 8 was chosen at random to 162 formulate additional three diets. The diets were pelleted at NIPH (The National 163 Institute of Poultry Husbandry) Harper Adams University using a laboratory pelleter 164 (KAHL, Amandus Kahl GmbH \& Co. KG, Reinbek, Germany). The frequency of 165 pelleter was $50 \mathrm{~Hz}$ and temperature of the jacket ranged between $44.5^{\circ} \mathrm{C}-46.5^{\circ} \mathrm{C}$. 166 Pellets were produced at temperature ranged between $59^{\circ} \mathrm{C}-62.5^{\circ} \mathrm{C}$. No steam was 167 used during pelleting. The whole pelleting process was in a controlled environment, 168 strictly monitoring speed of the feeder, frequency of pelleter, and temperature of 169 pellets produced. Pellets were cool down to ambient temperature by ventilated cool air 170 for 30 mins and then stored in bags. Pellets were stored at temperature below $18^{\circ} \mathrm{C}$. 171 The diameter and length of pellet was $3 \mathrm{~mm}$ and $4-7 \mathrm{~mm}$, respectively. Each 172 experimental diet met or exceeded the diet specification for Ross male 308 broiler 173 chickens (Aviagen Ltd. Edinburgh, UK). Diets were free of coccidiostats, 174 antimicrobial growth promoters or other similar additives. Pellet durability index 175 (PDI) was also determined in duplicates to test the pellet quality using a Holmen Pellet 176 Tester (NHP100 Portable Pellet Durability Tester, TekPro Ltd, Norfolk, UK). The 177 values of PDI ranged from 80.2 to $83.8 \%$. 


\section{Husbandry and sample collection}

179 All procedures were approved by Harper Adams University Research Ethics

180 Committee. Eight hundred (800), one day old male Ross 308 broilers were obtained

181 from a commercial hatchery, weighed individually and allocated randomly to 160

182 raised floor pens with $0.360 \mathrm{~m}^{2}$ solid floors area, five birds in each pen. Each diet was

183 randomly assigned to eight pens within blocks (positioned within the house) and fed

184 from 0 - 21 days. Feed and water were offered ad libitum to birds throughout the

185 experiment. Each pen was equipped with a feeding trough outside the pen and

186 automatic drinkers inside the pen. The temperature was maintained at $32^{\circ} \mathrm{C}$ for first

187 day of the study and was reduced gradually to $21^{\circ} \mathrm{C}$ at the end of study (d 21). A

188 standard lighting programme was followed decreasing the light: dark ratio from $23 \mathrm{~h}$ :

$1891 \mathrm{~h}$ from day old to $18 \mathrm{~h}: 6 \mathrm{~h}$ at $\mathrm{d}$ 7, which was maintained till $\mathrm{d} 21$ (Aviagen Ltd.

190 Edinburgh, UK). Birds were fed experimental wheat based mash diets during the first

191 seven days and pellet diets from 7 to $21 \mathrm{~d}$ of age. Body weights were recorded at the

192 beginning and at the end of experiment (d 21). The birds were inspected daily, and

193 dead birds were weighed at the time of removal. Feed intake per pen (FI) was recorded

194 and feed conversion ratio (FCR) was calculated on a pen weight basis. The body

195 weights of dead birds were included to calculate FCR.

196 Excreta collection

197 At d 18, the solid floor of each pen was replaced with a wire mesh and plastic trays 198 were placed underneath for excreta collection. Excreta were quantitatively collected 199 every 12 hours from each pen for three consecutive days (19 - 21 days) and 200 immediately dried at $60{ }^{\circ} \mathrm{C}$ in a forced draft oven, weighed and milled by Retsch ZM 201200 (Retsch GmbH, Haan, Germany) using a $0.75 \mathrm{~mm}$ screen. Feathers and scales 202 were removed carefully to avoid any contamination. The feed intake was recorded for 
203 the same period. The dry matter (DM) content, gross energy (GE), nitrogen and fat (as

204 ether extract) of excreta and the experimental diets were determined as described for

205 the wheat samples. All analyses were performed in duplicates. The AME values of the

206 diets on a dry matter basis were determined by equation (1).

$207 \mathrm{AME} \operatorname{diet}(\mathrm{MJ} / \mathrm{kg} \mathrm{DM})=\frac{\left(\text { Feed intake } \mathrm{x} G \mathrm{G}_{\text {diet }}\right)-\left(\text { Excreta output } \mathrm{x} G \mathrm{GE}_{\text {excreta }}\right)}{\text { Feed intake }}$ (1)

208 AMEn diet $(M J / k g D M)=\frac{((\text { Feed intake } \times \mathrm{GE} \text { diet })-(\text { Excreta output } \times \mathrm{GE} \text { excreta }))-\left(\mathrm{N}_{\text {retained }} \times \text { 34.39) }\right.}{\text { Feed intake }}$ (2)

209 Nutrient retention coefficient $=\frac{\text { (Feed intake } \mathrm{x} \text { Nutrient diet })-(\text { Excreta output } \mathrm{x} \text { Nutrient } \mathrm{excreta})}{\text { Feed intake } \mathrm{x} \text { Nutrient } \mathrm{diet}_{\mathrm{i}}}(3)$

$210 \quad \mathrm{AME}$ wheat $(\mathrm{MJ} / \mathrm{kg} \mathrm{DM})=\frac{\mathrm{AME}_{\text {diet }}-\left(\mathrm{AME}_{\text {balancer diet } \mathrm{X}} 0.33\right)}{0.67}(4)$

211 Nitrogen corrected AME (AMEn) was determined by correction for zero $\mathrm{N}$ retention

212 by multiplication with $34.39 \mathrm{MJ} / \mathrm{kg} \mathrm{N}$ retained in the body (2) as described by Hill and

213 Anderson (1958). The coefficients of nitrogen retention (NR), fat digestibility (FD)

214 and dry matter retention (DMR) were determined as the difference between nutrient

215 intake and excretion of each nutrient divided by nutrient intake (3).

216 The AME of wheat and coefficients of nutrient retention were calculated by

217 substitution method using equation (4). Linear regression analysis was used to test the

218 linear response of bioavailable energy and nutrient retention at four inclusion levels of

219 wheat $(470,570,670,770)$. There was a linear response $(P<0.05)$ to inclusion levels

220 of wheat for AME and AMEn and determined nutrients with no evidence of non-

221 linearity $(P>0.05)$. The AME and nutrient retention constant of balancer diet was

222 determined by linear regression analysis of diets $8,18,19,20$ and used in equation 4

223 to predict the AME and total tract nutrient retention of wheat. 
224 At the end of trial, at $21 \mathrm{~d}$ of age, all five birds in each pen were weighed and killed

225 by cervical dislocation. The contents of ileal digesta from Meckel's diverticulum to

226 ileal-caecal junction were gently pressed from each bird and pooled by pen,

227 homogenised, then centrifuged (10,000 x $\mathrm{g}$ for $2 \mathrm{~min})$. The viscosity of the supernatant

228 was measured using a rotating cone and cup viscometer (model DV - II + LV,

229 Brookfield Stoughton, MA, USA) as described by Bedford and Classen (1992).

\section{$230 \quad$ Statistical analysis}

231 Statistical analyses were performed in GenStat statistical software (GenStat 17th 232 edition supplied by VSN international Ltd, UK). Broiler growth performance, AME, 233 AMEn values of wheat samples and nutrient retention coefficients were subjected to 234 analysis of variance (ANOVA) in a randomised block design, with a single pen 235 representing experimental unit (replicate). Treatments and block were fixed effects. 236 The variables that described growth performance were feed intake gram per bird per 237 day (FI), weight gain gram per bird per day (WG), final body weight kilogram per bird 238 (BW), feed conversion ratio (FCR) corrected for mortality ( $\mathrm{g}$ of feed intake per $\mathrm{g}$ of 239 weight gain). Means were separated using Duncan multiple range test and differences 240 were significant at $P<0.05$. Least significant difference (LSD) test was used for 241 illustration purpose to report the significant differences.

242 Correlation coefficients were also generated to test for any linear relationships between

243 chemical composition and grain quality measurements of wheat samples with AME,

244 nutrient utilisation and growth performance of broilers. Relationships were reported at 245 significance level $(P<0.05 ; \mathrm{r}=0.482, P<0.01 ; \mathrm{r}=0.606$ and $P<0.1 ; \mathrm{r}=0.412)$. 246 Simple and stepwise multiple linear regression analysis was used to assess the 247 relationship between broiler growth performance, determined AME and characteristics 
248 of wheat samples (chemical composition and grain quality). A stepwise regression

249 technique was used to evaluate the effects of the independent variables into a linear

250 model. Chemical composition and grain quality measurements of wheat samples were

251 used as independent variables in stepwise regression. The variables FI, WG, FCR and

252 determined AME of wheat samples were used separately as dependent variables. The

253 independent variables were added one at a time in the model starting with highest

254 correlation with dependant variables. Contribution of each variable was analysed

255 statistically before entering next variable. If a nonsignificant variance was found, it

256 was removed from the model. Variables were added to independent variables until

257 there was no further improvement in variance and addition of variables were statistical

258 significance $(P<0.05)$ in the equation.

\section{Results}

\section{Chemical composition}

261 The chemical composition of seventeen wheat samples is summarised in Table 3. The

262 dry matter (DM) content varied in the range of 873 to $910 \mathrm{~g} / \mathrm{kg}$. The amount of protein 263 and fat (as ether extract) in wheat samples ranged from 97 to $143 \mathrm{~g} / \mathrm{kg} \mathrm{DM}$ and 10.9 264 to $17.4 \mathrm{~g} / \mathrm{kg} \mathrm{DM}$, respectively. The ash content between samples ranged from 12.8 to $26519.6 \mathrm{~g} / \mathrm{kg}$ DM. Gross energy (GE) was less variable between samples and ranged from 26617.81 to $18.24 \mathrm{MJ} / \mathrm{kg}$ DM. The amount of starch in the wheat samples varied from 671 267 to $728 \mathrm{~g} / \mathrm{kg}$ DM. The non-starch polysaccharides (NSP) content ranged from 80.1 to $26898.2 \mathrm{~g} / \mathrm{kg}$ DM. Soluble and insoluble NSP in wheat samples ranged from 11.2 to 23.2 $269 \mathrm{~g} / \mathrm{kg} \mathrm{DM}$ and 63.7 to $80.2 \mathrm{~g} / \mathrm{kg} \mathrm{DM}$, respectively. 


\section{Grain quality}

271 The values of Hagberg falling numbers (HFN) between seventeen wheat samples

272 ranged from 130 to 384 (Table 4). Endosperm hardness (EH) of wheat samples ranged

273 from 21 to 87 relative units (soft to hard). The values of HFN and EH were variable

274 between samples because of different wheat types (feed wheat, milling). The specific 275 weight (SW) of wheat samples ranged from 75.4 to $82.4 \mathrm{~kg} / \mathrm{hl}$. The thousand grain 276 weights (TGW) ranged between 45.7 to $59.9 \mathrm{~g}$. The dynamic water extract viscosity

277 (DV) ranged between 2.4 to $6 \mathrm{cP}$ (centipoise), whereas kinematic water extract 278 viscosity (KV) ranged between 1.17 to $1.56 \mathrm{cSt}$ (centistokes). Dry matter (DM) of all 279 experimental diets ranged from 890 to $916 \mathrm{~g} / \mathrm{kg} \mathrm{DM}$.

\section{Apparent metabolisable energy and nutrient utilisation}

281 The determined AME of seventeen individual wheat samples ranged from 13.68 to $28214.81 \mathrm{MJ} / \mathrm{kg} \mathrm{DM}\left(\mathrm{CV}^{\mathrm{m}}\right.$ (of 17 individual samples) $\left.=4.2 \%\right)$. The determined AMEn of wheat 283 samples ranged from 13.32 to $14.36 \mathrm{MJ} / \mathrm{kg} \mathrm{DM}\left(\mathrm{CV}^{\mathrm{m}}=4.1 \%\right)$, respectively (Table

284 5). There were differences $(P<0.05)$ in AME and AMEn between individual wheat 285 samples. There were also differences $(P<0.05)$ in GE metabolisability of wheat 286 samples and AME: GE ratio ranged from 0.762 to $0.822\left(\mathrm{CV}^{\mathrm{m}}=4.2 \%\right)$, similarly 287 AMEn: GE ratio ranged from 0.742 to $0.797\left(\mathrm{CV}^{\mathrm{m}}=4.1 \%\right)$.

288 There were no differences $(P>0.05)$ in the coefficient of total tract nitrogen retention 289 (NR) between the seventeen wheat samples. Differences were observed for 290 coefficients of fat digestibility (FD) and dry matter retention (DMR) $(P<0.05, P<$ 2910.001 , respectively) (Table 6). Nitrogen retention (NR) ranged from 0.545 to $0.607(\mathrm{CV}$ $\left.292{ }^{\mathrm{m}}=8.2 \%\right)$, FD ranged from 0.605 to $0.742\left(\mathrm{CV}^{\mathrm{m}}=11.6 \%\right)$ and DMR ranged from 2930.763 to $0.811,\left(\mathrm{CV}^{\mathrm{m}}=3.6 \%\right)$. 
295 There were differences $(P<0.05)$ in $\mathrm{FI}\left(\mathrm{CV}^{\mathrm{m}}=8.5 \%\right), \mathrm{WG}\left(\mathrm{CV}^{\mathrm{m}}=7.9 \%\right)$ and $\mathrm{BW}$ $296\left(\mathrm{CV}^{\mathrm{m}}=7.5 \%\right)$ of broilers fed seventeen wheat based diets (Table 6). Although, there 297 were differences in FI and WG of broilers but no differences $(P>0.05)$ in FCR were 298 observed between wheat samples and values of FCR ranged from 1.197 to 1.243 (CV $\left.299 \mathrm{~m}^{\mathrm{m}}=3.2 \%\right)$. There were no differences $\left(P>0.05, \mathrm{CV}^{\mathrm{m}}=26.3 \%\right)$ in ileal digesta 300 viscosity of broilers.

301 Relationship between characteristics of the wheat and AME and growth 302 performance

303 A correlation matrix was initially used to compare the relationships between wheat 304 samples laboratory analyses and AME and broiler growth performance (Table 7). Ash 305 was negatively correlated with AME and AMEn $(\mathrm{r}=0.513,0.489 ; P<0.05$, 306 respectively). There was a tendency of a negative relationship between insoluble NSP 307 and AME, AMEn $(\mathrm{r}=0.466,0.464 ; P<0.1)$. There were positive relationships 308 between the coefficients of NR, FD and AMEn $(\mathrm{r}=0.496,0.552 ; P<0.05$, 309 respectively). Dry matter retention (DMR) was positively correlated with AMEn $(\mathrm{r}=$ $3100.726 ; P<0.001)$. Broiler growth performance did not correlate $(P>0.05)$ with AME 311 and AMEn of the wheat samples.

312 Although, there were differences in FI and WG of broilers when they were fed different

313 wheat samples, there was no relationship $(P>0.05)$ between growth performance and 314 wheat chemical composition. Specific weight (SW) was the only characteristics of 315 wheat samples which was positively correlated $(\mathrm{r}=0.515 ; P<0.05)$ with FCR. Feed 316 intake of broilers was correlated $(\mathrm{r}=0.953 ; P<0.001)$ with WG of broilers. 
317 Stepwise multiple linear regression analysis indicated that wheat variables ash, soluble

318 NSP and CP in combination gave the best explanation $\left(\mathrm{r}^{2}=0.59 ; P<0.05\right)$ of variation

319 in AME of wheat but only accounted for $59 \%$ variability in AME. The addition of any

320 further explanatory variables did not significantly $(P>0.05)$ reduce residual mean

321 squares in AME. The determined AME and wheat characteristics variables were also

322 tested for non-linear regression, however there was no evidence of non-linear ( $\mathrm{P}>$

323 0.05) response between AME and wheat variables. There was no relationship $(P>$

3240.05 ) between the combination of wheat chemical composition, quality characteristics

325 and growth performance of chickens.

\section{Discussion}

327 The study evaluated the effect of wheat samples that represented the range and quality

328 of samples currently available to the UK poultry industry, with different chemical

329 composition and quality characteristics, on metabolisable energy, nutrient utilisation

330 of wheat and growth performance of broilers. The findings of this study are important

331 for nutritionists because a large set of currently available UK wheat samples for

332 poultry feeds were investigated and variability between different samples were

333 studied.

\section{Chemical composition}

335 The proximate nutrient composition and GE contents were in a similar range to earlier

336 studies (Preston et al. 2000; Rose et al. 2001; Amerah et al. 2008; Pirgozliev et al. 337 2015). The contents of $\mathrm{CP}$ were variable $(\mathrm{CV}=8.3 \%)$ between wheat samples, in 338 agreement with Hetland et al. (2007) and Gutierrez del Alamo et al. (2008a). The 339 amounts of total starch and NSP were in a similar range as reported by previous 340 findings (Annison 1990; Waldron 1997; McCracken and Quintin 2000; Carre et al. 
341 2005). Chemical composition of wheat varies due to numerous factors including

342 growing season, soil type, location, crop husbandry and genetic origin of the wheat

343 (Gutierrez del Alamo et al. 2008b, Ravindran and Amerah, 2009).

\section{Quality characteristics}

345 The values of HFN in wheat samples were in the similar range to earlier reported 346 results (Rose et al. 2001; Hetland et al. 2007), though their reported HFN were 347 generally higher than the values in present study, possibly due to differences in 348 growing condition, effect of weather and storage. Hagberg falling number was variable 349 between seventeen samples $(\mathrm{CV}=28.7 \%)$, and soft and hard milling wheats had 350 relatively high HFN as compared to feed wheat. High $\alpha$-amylase activity was recorded 351 in feed wheats (Leeds and Santiago) with a lower HFN. The relative units of EH were 352 in agreement of previous studies (Rose et al. 2001; Pirgozliev et al. 2003; Amerah et 353 al., 2008). Wheat endosperm hardness is an important characteristic in the quality of 354 wheat for bread making, cakes or biscuits. Hardness of wheat affects the milling 355 performance of the wheat. Hard wheat shatters when milled and the flour is fine, with 356 regular particle size and large surface area (Rose et al. 2001; Ball et al. 2013). The 357 specific weight of wheat samples were less variable between samples $(\mathrm{CV}=2.8 \%)$ 358 and agreed with previous findings (Wiseman 2000; McCracken et al. 2002; Gutierrez 359 del Alamo et al. 2008a).

\section{Energy availability, nutrient utilisation}

361 The differences in AME values of experimental wheat samples were in the expected 362 range and in agreement with previous findings (McCracken and Quintin 2000; 363 Steenfeldt 2001; Pirgozliev et al. 2003; Smeets et al. 2015). The values of AME 364 between individual wheat samples were significantly different $(P<0.05$; LSD $=0.60$ $365 \mathrm{MJ} / \mathrm{kg} \mathrm{DM}$ ), similarly AMEn values of individual wheat samples were also 
366 significantly different $(P<0.05 ; \mathrm{LSD}=0.57 \mathrm{MJ} / \mathrm{kg} \mathrm{DM})$. Some of the previous studies

367 reported no difference in AME between wheat samples (Wiseman 2000; Amerah et al.

368 2008), but only physical characteristics were measured in the former study, while only

369 two samples were analysed in the latter. In this study, maximum range of differences

370 in AME and AMEn between samples were 1.13 and $1.04 \mathrm{MJ} / \mathrm{kg} \mathrm{DM}$, respectively.

371 The AME value of sample 15 was $8.3 \%$ higher than lowest AME value sample 8 . The

$372 \mathrm{~N}$ corrected AME (AMEn) of sample 15 was $7.8 \%$ higher than the lowest AMEn

373 value sample 8 . The difference of $1 \mathrm{MJ} / \mathrm{kg}$ between samples is commercially important

374 in broiler feed formulation and indicates that there is important variation between

375 AME of different currently available UK wheat samples. The coefficients of NR, FD

376 and DMR results were in expected range and in accord with previous reports

377 (Steenfeldt 2001; Pirgozliev et al. 2015; Smeets et al. 2015). The values of DMR of

378 sample 15 were $6.15 \%$ higher than sample 8 which correspond to difference in AME

379 between these two samples. There was a difference of $21.5 \%$ in FD between average

380 lowest and highest values of wheat.

381 Relationship between chemical composition, quality characteristics, nutrient 382 utilisation and apparent metabolisable energy of wheat samples

383 There was no significant association of major energy yielding components of wheat

384 including starch and protein with AME. The only significant $(P<0.05)$ relationship 385 was, a negative association of ash with AME $\left(\mathrm{r}^{2}=0.21 ; P<0.05\right)$. Simple linear 386 regression analysis indicated that only $21 \%$ of the variation in AME was explained by 387 the ash contents of wheat samples. The results of stepwise multiple linear regression 388 analysis indicated that only $59 \%$ variability in AME of studied wheat samples was 389 explained $(P<0.05)$ when ash, soluble NSP and CP were used in combination. The 390 addition of any other chemical composition variables of wheat did not further explain 
391 variability in AME. Researchers have found negative correlation between CP and

392 AME (Svihus and Gullord 2002; Ball et al. 2013) but this study indicated only a

393 tendency for a negative correlation between CP of wheat samples with AME and

394 AMEn. The tendency of a negative association between insoluble NSP and AME was

395 in accord with previous published data (Annison 1991, 1993; Smeets et al. 2015).

396 Studies had indicated that variation in NSP content of wheat could affect ME and

397 broilers growth performance (Choct et al. 1995; Hetland et al. 2004). Non-starch

398 polysaccharides are encapsulated within the cell wall, making it difficult for

399 endogenous enzyme to release them. Most of the arabinoxylans in wheat are insoluble

400 and inaccessible to birds as nutrients (Bedford and Morgan 1996; Choct 2006). In this

401 study, there were variations $(\mathrm{CV}=23.1 \%)$ in soluble NSP content of wheat samples;

402 however, there was no significant association of soluble NSP with AME, which were

403 in agreement of previous findings (Steenfeldt 2001; Choct et al. 2006). The tendency

404 of relationship between soluble NSP and ileal digesta viscosity $(r=0.444, \mathrm{P}<0.1)$

405 suggests that soluble NSP are not always associated with a reduction in ME by

406 increasing ileal digesta viscosity. The lack of relationship between starch and AME

407 was not surprising and has been reported previously (McCracken et al. 2002; Gutierrez

408 del Alamo et al. 2008a). Starch and protein are encapsulated by the cell wall in wheat

409 endosperm cells. Steam conditioning during pelleting can damage cell walls to release

410 starch, resulting in improved ME. In the present study, diets were pelleted without

411 steam, and absence of steam conditioning may not release starch completely. The

412 absence of relationship of starch with AME could also be due to less variability (CV

$413=2.2 \%$ ) in starch contents of studied wheat samples.

414 The lack of correlation between SW and AME confirmed previous reports (Wiseman

415 2000; Svihus and Gullord 2002) and could be due to less variation in SW (CV = 2.8 
$416 \%$ ) between wheat samples. Specific weight is most commonly used by feed millers to

417 accept wheat samples based on their yield $(\mathrm{kg} / \mathrm{hl})$. High yield varieties do not always

418 correspond to high AME. In this study, the quality characteristics of wheat samples

419 did not relate to AME, which indicated that quality characteristics cannot be relied

420 upon to determine the feeding value of wheat. Researchers so far have been unable to

421 establish a consistent relationship between wheat quality characteristics and AME

422 (McCracken et al. 2002; Hetland et al. 2007; Ball et al. 2013). A significant positive

423 correlation between FD and AMEn confirmed previous results of Steenfeldt (2001)

424 and could be due to high variability $(\mathrm{CV}=11.6 \%)$ in FD. In this study, the positive

425 relationship between FD and AMEn indicated that although starch is the main energy

426 yielding component in wheat, high FD may also contribute towards higher AMEn of

427 wheat to some extent, though this contribution is not significant enough to be

428 accounted for major variation in AMEn. The positive correlation between nutrient

429 digestibility and AMEn indicates that AMEn is only improved if diets have highly

430 digestible nutrients and alongside starch, other nutrients contribute towards available

431 energy from wheat.

432 Relationship between chemical composition, quality characteristics of wheat 433 samples and growth performance of broilers

434 The current study revealed that there were large differences $(13-14 \%)$ in FI and 435 growth rate of broilers, which cannot be fully explained by the wheat chemical 436 composition. The tendency of relationship between ash content of wheat samples and 437 WG was in agreement with the previous work of Pirgozliev et al. (2003). The 438 variations in ash content of wheat samples could be due to soil contamination.

439 The current study reported no relationship between EH of wheat samples and growth 440 performance. The published literature on the effect of EH on growth performance is 
441 inconsistent. Rose et al. (2001) reported a positive correlation between endosperm

442 hardness and feed intake and weight gain. Amerah et al. (2008) found increase in feed

443 intake of broilers fed soft wheat-based diets supplemented with enzyme, but no

444 improvement in hard wheat. Salah Uddin et al. (1996) reported no effect of endosperm

445 hardness on broiler performance in pellet diet. Pirgozliev et al. (2016) compared pellet

446 versus mash diets containing wheat with soft and hard endosperm and only found

447 differences in FI and WG of broilers fed on pellet diets. Soft wheat tends to produce

448 flour with smaller surface area and relatively little starch damage due to intact starch

449 granules, while in hard wheat particles are large with irregular shapes and starch

450 granules are cleaved (Rose et al. 2001). Cleaved starch granules solubilise more

451 quickly than when they are intact. Endosperm hardness may influence the quality of

452 pellet. Hard endosperm produces good quality pellets because of large particle size

453 and absorb more water during pelleting process which helps in gelatinisation

454 (Abdollahi et al. 2011, 2013). However, this study was unable to detect any effect of

455 EH on growth performance of broilers, although, there was a range $(21-87)$ in relative

456 units of EH of studied wheat samples.

457 The lack of association between HFN and growth performance confirmed findings of

458 Hetland et al. (2007). The reported effect of HFN on growth performance are

459 inconsistent (Rose et al. 2001, Svihus and Gullord 2002) and require further

460 investigation. Hagberg falling number is used in the milling industry to access the

461 wheat suitability for bread making, and a high HFN is considered to produce a good

462 quality loaf for bread making. Hagberg falling number is a measure of $\alpha$ - amylase

463 activity to determine pre-harvest sprouting. High $\alpha$-amylase activity means less

464 viscous wheat flour upon gelatinisation. The positive correlation between SW of wheat

465 and FCR was interesting and in line with previous works (McCracken and Quintin 
4662000 ; Ball et al. 2013), but SW did not correlate to any of the other broiler performance

467 attributes, so making it difficult to explain this relationship.

468 The absence of a relationship between growth performance and AME in this study 469 agreed with previous findings (Steenfeldt 2001; Ball et al. 2013; Pirgozliev et al. 470 2015). The differences in AME of wheat samples examined in this study are not clearly 471 related to variations in wheat chemical composition or quality characteristics. Wheat 472 provides high proportion of ME (up to $70 \%$ ) in practical broilers diets and any 473 differences in AME between different wheat samples are important. However, this 474 study has confirmed that care should be taken in using wheat chemical composition 475 and quality characteristics information as predictor of AME of individual wheat 476 samples.

477 In the present experiment, there were significant differences in FI and growth rate of 478 broilers when fed diets comprising different individual wheat samples. Broilers fed 479 diet containing wheat sample 8 had $14.3 \%$ and $13.8 \%$ higher FI and WG, respectively 480 as compared to sample 2. In this study, differences were unlikely due to differences in 481 protein contents of wheat samples because all diets were made isonitrogenous and had 482 same amino acid balance. This magnitude of difference in broiler growth performance 483 would be commercially important for the broiler feed industry. Conversely, there were 484 no differences between fifteen (15) out of seventeen (17) wheat samples. Wheat 485 samples two (2) and seven (7) were the samples which had significant low growth rate 486 in broilers as compared to other fifteen samples. Further examination of data indicated 487 that these two samples did not have any obvious difference in their chemical 488 composition and quality characteristics. Steenfeldt (2001) also reported $14 \%$ 489 reduction in growth rate of broilers when fed diets containing different wheat cultivars 
490 at similar inclusion $(65 \%)$ of wheat. The results of this study suggest that perhaps

491 nutritionists can identify samples that give poor growth rate. In this study, broilers with

492 low growth rate also had lower voluntary feed intakes. The rate of starch digestion

493 could possibly be a factor in investigating the differences in feed intake of broiler

494 chickens. Liu et al. (2013) have found differences in growth rate of broilers when fed

495 diets with different rate of starch digestion.

496 In conclusion, the current UK wheat samples examined in this study varied in their

497 chemical composition and quality characteristics. The results indicated that apparent

498 metabolisable energy of currently available UK wheat samples is variable. Ideally, the

499 AME of individual batches of wheat samples would be considered at diet formulation

500 stage at commercial feed mills so it would require a robust prediction method. This

501 study has not been able to specify that wheat chemical composition and quality

502 characteristics can be used for determination of AME. The present study indicated that

503 there was no association of wheat characteristics with AME. The study also illustrated

504 no clear association of starch and protein with AME but would be interesting to

505 investigate the relationship between digestibility of macronutrients and AME.

506 The present study has demonstrated that there are substantial differences in growth

507 rate of broilers fed different wheat samples, although no difference in feed efficiency

508 was identified. High growth rate in broilers is important because birds can achieve live

509 weight gain at a faster rate resulting in a shorter production cycle. In this study,

510 difference in FI and WG were not related to AME or any single or combination of

511 chemical composition and quality characteristics of wheat. Differences in feed intake

512 of broilers fed different wheat samples warrant further investigations. 


\section{Acknowledgements}

514 The authors wish to acknowledge the support of technicians Richard James and

515 Rosalind Crocker. The authors would also like to thanks KWS UK Ltd for providing 516 wheat samples for this study.

\section{Disclosure statement}

518 No potential conflict of interest was reported by the authors. 


\section{References}

520

521 ABDOLLAHI, M., V. RAVINDRAN, T. WESTER, G. RAVINDRAN, and D. 522 THOMAS. 2011. "Influence of Feed Form and Conditioning Temperature on 523 Performance, Apparent Metabolisable Energy and Ileal Digestibility of Starch and 524 Nitrogen in Broiler Starters Fed Wheat-Based Diet." Animal Feed Science and 525 Technology 168 (1-2): 88-99. doi:10.1016/j.anifeedsci.2011.03.014.

526 ABDOLLAHI, M. R., V. RAVINDRAN, and B. SVIHUS. 2013. "Pelleting of Broiler 527 Diets: An Overview with Emphasis on Pellet Quality and Nutritional 528 Value." Animal Feed Science and Technology 179 (1-4): 1-23. 529 doi:10.1016/j.anifeedsci.2012.10.011.

530 AHDB. 2016. AHDB Recommended List 2016/17 for Cereal and Oilseeds. 531 Warwickshire, UK. https://cereals.ahdb.org.uk/media/883980/1-RLDL_2016532 17_Winter_Wheat_RL-V6.pdf

533 AHDB. 2015. AHDB Recommended list 2015/2016 for Cereals and Oilseeds. $534 \quad$ Warwickshire, UK. https://cereals.ahdb.org.uk/media/576554/recl1516$535 \quad$ recommended-list-2015-2016-summer-edition.pdf

536 AMERAH, A., V. RAVINDRAN, and R. LENTLE. 2008. "Influence of Wheat 537 Hardness and Xylanase Supplementation on the Performance, Energy Utilisation, 538 Digestive Tract Development and Digesta Parameters of Broiler Starters.” Animal $539 \quad$ Production Science 49 (1): 71-78. doi:10.1071/EA08162. 
540 ANNISON, G. 1990. "Polysaccharide Composition of Australian Wheats and the 541 Digestibility of their Starches in Broiler Chicken Diets." Australian Journal of $542 \quad$ Experimental Agriculture 30 (2): 183-186.

543 ANNISON, G. 1991. "Relationship between the Levels of Soluble Non-starch

544 Polysaccharides and the Apparent Metabolizable Energy of Wheats Assayed in $545 \quad$ Broiler Chickens." Journal of Agricultural and Food Chemistry 39 (7): 12525461256.

547 ANNISON, G. 1993. "The Role of Wheat Non-Starch Polysaccharides in Broiler $548 \quad$ Nutrition.” Australian Journal of Agricultural Research 44 (3): 405-422.

549 AOAC. 2012. Official Methods of Analysis, 19th edition. Association of Official $550 \quad$ Analytical Chemists, Gaithersburg, USA.

551 AVIAGEN. "Ross 308 Broiler Nutrition Specifications 2014.” www.aviagen.com

552 BALL, M. E., B. OWENS, and K. J. MCCRACKEN. 2013. "Chemical and Physical 553 Predictors of the Nutritive Value of Wheat in Broiler Diets." Asian-Australasian $554 \quad$ Journal of Animal Sciences 26 (1): 97-107. doi:10.5713/ajas.2012.12178.

555 BEDFORD, M. R. and H. L. CLASSEN. 1992. "Reduction of Intestinal Viscosity 556 through Manipulation of Dietary Rye and Pentosanase Concentration is Effected 557 through Changes in the Carbohydrate Composition of the Intestinal Aqueous 558 Phase and Results in Improved Growth Rate and Food Conversion Efficiency of 559 Broiler Chicks." The Journal of Nutrition 122 (3): 560-569. 
560 BEDFORD, M. and A. MORGAN. 1996. "The use of Enzymes in Poultry Diets." World's Poultry $\quad$ Science $\quad$ Journal $52 \quad$ (1): 61-68. doi:10.1079/WPS19960007.

CARRÉ, B., N. MULEY, J. GOMEZ, F. -. OURY, E. LAFFITTE, D. GUILLOU, and C. SIGNORET. 2005. "Soft Wheat Instead of Hard Wheat in Pelleted Diets Results in High Starch Digestibility in Broiler Chickens." British Poultry Poultry Science Journal 62 (1): 5-16.

CHOCT, M. and G. ANNISON. 1992a. "Anti-nutritive Activity of Wheat Pentosans in Broiler Chickens: Roles of Viscosity and gut Microflora." British Poultry Science 33: 821-834. Wheat Pentosans.” British Journal of Nutrition 67 (01): 123-132.

574 CHOCT, M., M. SINLAE, R. A. M. AL-JASSIM, and D. PETTERSSON. 2006. 575 "Effects of Xylanase Supplementation on between -Bird Variation in Energy 576 Metabolism and the Number of Clostridium Perfringens in Broilers Fed a Wheat Based Diet.” Australian Journal of Agriculture Research (57): 1017-1021.

578 CHOCT, M., R. J. HUGHES, R. P. TRIMBLE, K. ANGKANAPORN, and G. 579 ANNISON. 1995. "Non-Starch Polysaccharide-Degrading Enzymes Increase the 580 Performance of Broiler Chickens Fed Wheat of Low Apparent Metabolizable 581 Energy." The Journal of Nutrition 125 (3): 485-492. 
582

583

584

585

586

587

588

589

590

591

592

593

594

595

596

597

598

599

600

601

602

ENGLYST, H. N., M. E. QUIGLEY, and G. J. HUDSON. 1994. "Determination of Dietary Fibre as Non-Starch Polysaccharides with gas-liquid Chromatographic, High-Performance Liquid Chromatographic or Spectrophotometric Measurement of Constituent Sugars.” Analyst 119 (7): 1497-1509.

ENGLYST, KLAUS N., GEOFFREY J. HUDSON, and HANS N. ENGLYST, eds. 2000. Starch Analysis in Food: Wiley Online Library. doi.org/10.1002/9780470027318.a1029.

FINNEY, D. J., ed. 1978. Statistical Method in Biological Assay. 3rd ed. Charles Griffin \& Co, London and High Wycombe.

GUtierreZ DEL AlAmo, A., M. W. Verstegen, L. A. DEN HARTOG, P. PEREZ DE AYALA, and M. J. VILLAMIDE. 2008a. "Effect of Wheat Cultivar and Enzyme Addition to Broiler Chicken Diets on Nutrient Digestibility, Performance, and Apparent Metabolizable Energy Content.” Poultry Science 87 (4): 759-767. doi:10.3382/ps.2007-00437.

GUTIERREZ-ALAMO, A., P. P. DE AYALA, M. VERSTEGEN, L. DEN HARTOG, and M. VILLAMIDE. 2008b. "Variability in Wheat: Factors Affecting its Nutritional Value."World's Poultry Science Journal 64 (1): 20-39. doi:10.1017/S0043933907001699.

HETLAND, H., M. CHOCT, and B. SVIHUS. 2004. "Role of Insoluble Non-Starch Polysaccharides in Poultry Nutrition.” World's Poultry Science Journal 60 (4): 415-422. doi:10.1079/WPS200325. 
603

604

605

606

607

608

609

610

611

612

613

614

615

616

617

618

619

620

621

622

HETLAND, H., A. UHLEN, K. VIKEN, T. KREKLING, and B. SVIHUS. 2007. "Hagberg Falling Number and the Nutritional Value of Wheat in Broiler Chicken Diets.” British Poultry Science 48 (1): 12-20. doi:10.1080/00071660601045763.

HILL, F. and D. ANDERSON. 1958. "Comparison of Metabolizable Energy and Productive Energy Determinations with Growing Chicks.” Journal of Nutrition 64: 587-603.

LIU, S., P. SELLE, and A. COWIESON. 2013. "The Kinetics of Starch and Nitrogen Digestion Regulate Growth Performance and Nutrient Utilisation of Broilers Fed Coarsely Ground, Sorghum-Based Diets.” Animal Production Science 53 (10): 1033-1040.

McCRACKEN, K., C. PRESTON, and C. BUTLER. 2002. "Effects of Wheat Variety and Specific Weight on Dietary Apparent Metabolisable Energy Concentration and Performance of Broiler Chicks.” British Poultry Science 43 (2): 253-260. doi:10.1080/00071660120121472.

McCRACKEN, K. and G. QUINTIN. 2000. “Metabolisable Energy Content of Diets and Broiler Performance as Affected by Wheat Specific Weight and Enzyme Supplementation.” British Poultry $\quad$ Science $41 \quad$ (3): $\quad 332-342$. doi:10.1080/713654927.

McNAB, J. 1991. "Factors affecting the nutritive value of wheat for poultry." HGCA Project Report No 43. London. 
623 PIRGOZLIEV, V., M. W. MIRZA, and S. P. ROSE. 2016. "Does the Effect of 624 Pelleting Depend on the Wheat Sample when Fed to Chickens?" Animal 10 (4): 571-577. doi:10.1017/S1751731115002311.

626

PIRGOZliEV, V., S. P. ROSE, T. PELlNY, A. M. AMERAH, M. WICKRAMASINGHE, M. ULKER, M. RAKSZEGI, Z. BEDO, P. R. SHEWRY, and A. LOVEGROVE. 2015. "Energy Utilization and Growth Performance of Chickens Fed Novel Wheat Inbred Lines Selected for Different Pentosan Levels with and without Xylanase Supplementation.” Poultry Science 94 (2): 232-239. doi:10.3382/ps/peu059.

PIRGOZLIEV, V. R., C. L. BIRCH, S. P. ROSE, P. S. KETTLEWELL, and M. R. BEDFORD. 2003. "Chemical Composition and the Nutritive Quality of Different Wheat Cultivars for Broiler Chickens.” British Poultry Science 44 (3) 464-475:

PRESTON, C., K. MCCRACKEN, and A. MCALLISTER. 2000. "Effect of Diet 464-938. doi:10.1080/0007166031000085594. Form and Enzyme Supplementation on Growth, Efficiency and Energy Utilisation

RAVINDRAN, V., and A. M. AMERAH. 2009. "Wheat: Composition and Feeding

642 Science Publisher, Inc, Hauppauge, NY, USA: 245-259.

ROSE, S., L. TUCKER, P. KETTLEWELL, and J. COLLIER. 2001. "Rapid Tests of 644 Wheat Nutritive Value for Growing Chickens." Journal of Cereal Science 34 (2): 181-190. doi:10.1006/jcrs.2001.0390. 
646 SALAH UDDIN, M. S., S. ROSE, T. HISCOCK, and S. BONNET. 1996. "A 647 Comparison of the Energy Availability for Chickens of Ground and Whole Grain $648 \quad$ Samples of Two Wheat Varieties.” British Poultry Science 37 (2): 347-357.

649 SAULNIER, L., N. PENEAU, and J. -. THIBAULT. 1995. "Variability in Grain 650 Extract Viscosity and Water-Soluble Arabinoxylan Content in Wheat.” Journal 651 of Cereal Science 22: 259-264. doi:10.1006/jcrs.1995.0062.

SCOTT, T., F. SILVERSIDES, H. CLASSEN, M. SWIFT, and M. BEDFORD. 1998. "Effect of Cultivar and Environment on the Feeding Value of Western Canadian Wheat and Barley Samples with and without Enzyme 655 Supplementation.” Canadian Journal of Animal Science 78 (4): 649-656.

SMEETS, N., F. NUYENS, L. V. CAMPENHOUT, E. DELEZIE, J. 1584-3174. doi:10.3382/ps/pev116.

STEENFELDT, S. 2001. "The Dietary Effect of Different Wheat Cultivars for Broiler 662 Chickens.” British Poultry Science 42(5):595-609.

663 SVIHUS, B. and M. GULLORD. 2002. "Effect of Chemical Content and Physical 664 Characteristics on Nutritional Value of Wheat, Barley and Oats for 665 Poultry." Animal Feed Science and Technology 102 (1): 71-92. 666 doi:10.1016/S0377-8401(02)00254-7. 
667 WALDRON, L. A. 1997. "The Nutritive Value of Different Wheat Varieties for 668 Broiler Chickens.” PhD Thesis. Harper Adams Agriculture College, Newport, $669 \quad$ UK.

670 WISEMAN, J. 2000. “Correlation between Physical Measurements and Dietary 671 Energy Values of Wheat for Poultry and Pigs.” Animal Feed Science and 672 Technology 84 (1): 1-11. doi:10.1016/S0377-8401(00)00107.

673 WISEMAN, J., N. NICOL, and G. NORTON. 2000. "Relationship between Apparent 674 Metabolisable (AME) Values and in vivo/in Vitro Starch Digestibility of Wheat 675 for Broilers.” World's Poultry Science Journal 56 (4): 305-318. 
676 Table 1. List of experimental wheat samples.

\begin{tabular}{clllr}
\hline Sample ID & Variety & Growing site & Type* & Usage \\
\hline 1 & Leeds & Nottinghamshire & Feed (Soft) & Feed wheat \\
2 & Leeds & Yorkshire & Feed (Soft) & Feed wheat \\
3 & Leeds & Lincolnshire & Feed (Soft) & Feed wheat \\
4 & Leeds & Cambridgeshire & Feed (Soft) & Feed wheat \\
5 & KWS Santiago & Yorkshire & Feed (Hard) & Feed wheat \\
6 & KWS Santiago & Nottinghamshire & Feed (Hard) & Feed wheat \\
7 & KWS Santiago & Lincolnshire & Feed (Hard) & Feed wheat \\
8 & KWS Santiago & Cambridgeshire & Feed (Hard) & Feed wheat \\
9 & KWS Lili & Yorkshire & Milling (Hard) & Bread \\
10 & KWS Lili & Yorkshire & Milling (Hard) & Bread \\
11 & KWS Trinity & Yorkshire & Milling (Hard) & Bread \\
12 & KWS Trinity & Yorkshire & Milling (Hard) & Bread \\
13 & KWS Trinity & Lincolnshire & Milling (Hard) & Bread \\
14 & KWS Trinity & Cambridge & Milling (Hard) & Bread \\
15 & KWS Barrel & Lincolnshire & Milling (Soft) & Cakes, biscuits \\
16 & KWS Barrel & Cambridgeshire & Milling (Soft) & Cakes, biscuits \\
17 & KWS Basset & Cambridgeshire & Milling (Soft) & Cakes, biscuits \\
\hline
\end{tabular}

677 *Varieties are listed on AHDB (Agriculture and horticulture development board) recommended list $6782016 / 2017$ 
679 Table 2. Ingredient and chemical composition ( $\mathrm{g} / \mathrm{kg}$ as-fed) 680 of the experimental balancer formulation.

\begin{tabular}{|c|c|}
\hline Item & $\mathrm{g} / \mathrm{kg}$ \\
\hline \multicolumn{2}{|l|}{ Dietary ingredients } \\
\hline Soybean meal (48) & 521.3 \\
\hline Full fat soybean meal & 299.2 \\
\hline Soya oil & 60.5 \\
\hline Monocalcium phosphate & 35.4 \\
\hline Limestone & 40.9 \\
\hline $\mathrm{NaCl}$ & 9.1 \\
\hline L-Lysine-HCL & 9.1 \\
\hline DL Methionine & 12.4 \\
\hline \multirow[t]{2}{*}{ Vitamin mineral premix $^{1}$} & 12.1 \\
\hline & 1000 \\
\hline \multicolumn{2}{|l|}{ Calculated analysis } \\
\hline $\mathrm{CP}(\mathrm{g} / \mathrm{kg})$ & 374.5 \\
\hline $\mathrm{ME}(\mathrm{MJ} / \mathrm{kg})$ & 12.45 \\
\hline Crude fat $(\mathrm{g} / \mathrm{kg})$ & 119.3 \\
\hline $\mathrm{Ca}(\mathrm{g} / \mathrm{kg})$ & 23.3 \\
\hline Available P (g/kg) & 9.7 \\
\hline Lysine (g/kg) & 31.3 \\
\hline Methionine + Cysteine $(\mathrm{g} / \mathrm{kg})$ & 20.4 \\
\hline Tryptophan (g/kg) & 4.6 \\
\hline \multicolumn{2}{|l|}{ Analysed values } \\
\hline $\mathrm{DM}(\mathrm{g} / \mathrm{kg})$ & 915 \\
\hline $\mathrm{GE}(\mathrm{MJ} / \mathrm{kg})$ & 18.03 \\
\hline CP (Nx6.25) (g/kg) & 369 \\
\hline Crude Fat $(\mathrm{g} / \mathrm{kg})$ & 127 \\
\hline
\end{tabular}

681 The balancer was fed as a part of complete diet comprising of $645 \mathrm{~g} / \mathrm{kg}$ of each

682 experimental wheat sample, mixture of wheat protein isolate and starch $25 \mathrm{~g} / \mathrm{kg}$

683 and $330 \mathrm{~g} / \mathrm{kg}$ of the balancer. Each experimental diet met or exceeded the diet

684 specification for Ross 308 male broilers (Aviagen Ltd, Edinburgh, UK).

$685{ }^{1}$ The vitamin and mineral premix contained vitamins and trace elements to

686 meet the breeder's recommendations (Aviagen Ltd, Edinburgh, UK).

687 The premix provided (units/kg diet): retinol, $12000 \mathrm{IU}$; cholecalciferol,

$6885000 \mathrm{IU}$; $\alpha$-tocopherol 34mg; menadione, $3 \mathrm{mg}$; thiamine, $2 \mathrm{mg}$; riboflavin,

$6897 \mathrm{mg}$; pyridoxine,5mg; cobalamin, $15 \mu \mathrm{g}$; nicotinic acid,50mg; pantothenic acid,

$69015 \mathrm{~g}$; folic acid,1 $\mathrm{mg}$; biotin, $200 \mu \mathrm{g}$; $80 \mathrm{mg}$ Fe as iron sulphate $(30 \%)$;

$69110 \mu \mathrm{g} \mathrm{Cu}$ as copper sulphate (25\%); 100mg Mn as manganous oxide (62\%);

$69280 \mathrm{mg} \mathrm{Zn}$ as zinc oxide (72\%); $1 \mathrm{mg} \mathrm{I}$ as calcium iodate (52\%);

$6930.2 \mathrm{mg}$ Se as sodium selenite (4.5\%) and $0.5 \mathrm{mg}$ Mo as sodium molybdate (40\%). 
Table 3. Chemical composition of seventeen wheat samples (g/kg DM).

\begin{tabular}{|c|c|c|c|c|c|c|c|c|c|}
\hline \multirow[b]{2}{*}{$\begin{array}{l}\text { Wheat } \\
\text { samples }\end{array}$} & \multicolumn{5}{|c|}{ Proximate nutrient } & \multicolumn{4}{|c|}{ Polysaccharide composition } \\
\hline & $\begin{array}{c}\text { Dry } \\
\text { Matter }\end{array}$ & Protein & $\mathrm{GE}^{1}$ & Fat & Ash & Starch & $\mathrm{NSP}^{2}$ & $\mathrm{sNSP}^{3}$ & insNSP $^{4}$ \\
\hline 1 & 873 & 143 & 18.11 & 10.9 & 19.6 & 678 & 98.2 & 17.9 & 80.2 \\
\hline 2 & 905 & 117 & 17.94 & 16.4 & 16.0 & 704 & 92.8 & 21.3 & 71.5 \\
\hline 3 & 882 & 127 & 17.88 & 12.9 & 15.3 & 704 & 90.5 & 16.2 & 74.2 \\
\hline 4 & 887 & 116 & 17.81 & 12.4 & 12.8 & 696 & 87.7 & 13.8 & 73.9 \\
\hline 5 & 904 & 117 & 17.89 & 16.1 & 15.9 & 697 & 86.6 & 15.1 & 71.4 \\
\hline 6 & 877 & 138 & 18.13 & 14.9 & 17.9 & 722 & 90.6 & 18.4 & 72.2 \\
\hline 7 & 898 & 116 & 17.98 & 17.4 & 16.2 & 671 & 80.1 & 12.3 & 67.8 \\
\hline 8 & 890 & 123 & 17.94 & 13.9 & 18.0 & 728 & 87.7 & 11.2 & 76.4 \\
\hline 9 & 898 & 122 & 18.03 & 15.0 & 16.3 & 699 & 86.7 & 18.8 & 67.9 \\
\hline 10 & 904 & 117 & 18.09 & 14.4 & 15.1 & 704 & 90.7 & 22.6 & 68.2 \\
\hline 11 & 910 & 126 & 18.24 & 12.7 & 16.9 & 707 & 82.2 & 11.3 & 71.0 \\
\hline 12 & 904 & 119 & 18.06 & 15.7 & 16.4 & 727 & 86.9 & 23.2 & 63.7 \\
\hline 13 & 891 & 127 & 18.00 & 15.4 & 14.2 & 708 & 83.5 & 15.9 & 67.6 \\
\hline 14 & 893 & 116 & 17.97 & 15.9 & 14.8 & 715 & 84.7 & 13.6 & 71.1 \\
\hline 15 & 886 & 122 & 18.02 & 17.1 & 14.9 & 704 & 92.9 & 21.7 & 71.2 \\
\hline 16 & 902 & 114 & 17.98 & 11.6 & 15.3 & 709 & 87.5 & 17.3 & 70.3 \\
\hline 17 & 891 & 97 & 17.81 & 14.8 & 17.2 & 726 & 87.4 & 13.9 & 73.5 \\
\hline Mean & 894 & 121 & 17.99 & 16.0 & 14.6 & 706 & 88.0 & 16.7 & 71.3 \\
\hline $\mathrm{CV} \%$ & 1.2 & 8.3 & 0.63 & 9.8 & 13.0 & 2.2 & 4.9 & 23.1 & 5.3 \\
\hline
\end{tabular}

695 Gross energy (MJ/kg DM) mega joules/kilogram on dry matter.

$696{ }^{2}$ Non-starch polysaccharides.

697 Soluble non-starch polysaccharides.

698 4insoluble non-starch polysaccharides

699 CV \%: represents variations between seventeen wheat samples. 
700 Table 4. Quality characteristics of seventeen wheat samples.

\begin{tabular}{ccccccc}
\hline $\begin{array}{c}\text { Wheat } \\
\text { samples }\end{array}$ & $\mathrm{HFN}^{1}$ & $\mathrm{EH}^{2}$ & $\begin{array}{c}\mathrm{SW}^{3} \\
(\mathrm{~kg} / \mathrm{hl}))\end{array}$ & $\begin{array}{c}\mathrm{TGW}^{4} \\
(\mathrm{~g})\end{array}$ & $\begin{array}{c}\mathrm{DV}^{5} \\
(\mathrm{cP})\end{array}$ & $\begin{array}{c}\mathrm{KV}^{6} \\
(\mathrm{cSt})\end{array}$ \\
\hline 1 & 240 & 35 & 77.8 & 45.7 & 3.4 & 1.56 \\
2 & 233 & 32 & 82.3 & 52.3 & 6.0 & 1.44 \\
3 & 130 & 26 & 76.6 & 48.6 & 3.9 & 1.32 \\
4 & 210 & 21 & 78.6 & 52.6 & 4.5 & 1.32 \\
5 & 181 & 87 & 80.0 & 52.4 & 3.4 & 1.29 \\
6 & 291 & 82 & 75.4 & 46.3 & 4.6 & 1.42 \\
7 & 197 & 71 & 78.1 & 52.6 & 2.6 & 1.17 \\
8 & 241 & 75 & 81.3 & 52.9 & 2.7 & 1.20 \\
9 & 301 & 85 & 81.8 & 50.9 & 3.6 & 1.39 \\
10 & 308 & 74 & 80.2 & 50.2 & 3.8 & 1.27 \\
11 & 380 & 79 & 82.4 & 53.2 & 4.4 & 1.42 \\
12 & 374 & 68 & 79.0 & 55.1 & 4.3 & 1.49 \\
13 & 368 & 64 & 77.2 & 54.7 & 2.8 & 1.42 \\
14 & 384 & 56 & 80.8 & 59.9 & 2.4 & 1.27 \\
15 & 237 & 30 & 77.1 & 54.4 & 2.8 & 1.30 \\
16 & 252 & 27 & 82.3 & 59.6 & 2.7 & 1.27 \\
17 & 206 & 31 & 78.7 & 59.4 & 2.5 & 1.30 \\
Mean & 266 & 55 & 79.4 & 53.0 & 3.5 & 1.34 \\
CV \% & 28.7 & 43.7 & 2.8 & 7.8 & 27.5 & 7.71 \\
\hline
\end{tabular}

701 ${ }^{1}$ Hagberg falling numbers, ${ }^{2}$ Endosperm hardness (relative units 0-120 soft-hard), ${ }^{3}$ Specific weight,

$702{ }^{4}$ Weight of 1000 kernels of wheat, ${ }^{5}$ Dynamic water extract viscosity (centipoise), ${ }^{6}$ Kinematic water 703 extract viscosity (centistokes).

704 CV \%: represents variations between seventeen wheat samples. 
705 Table 5. The effect of wheat samples on ${ }^{1}$ apparent metabolisable energy (AME MJ/kg 706 DM), N-corrected apparent metabolisable energy (AMEn MJ/kg DM), gross energy 707 metabolisability (GE J/J), coefficient of nitrogen retention (NR), fat digestibility (FD) 708 and dry matter retention (DMR) (data based on total collection from 19 to 21 days of 709 age).

\begin{tabular}{|c|c|c|c|c|c|c|c|}
\hline $\begin{array}{l}\text { Wheat } \\
\text { samples }\end{array}$ & AME & AMEn & AME:GE & AMEn:GE & NR & FD & DMR \\
\hline 1 & $14.00^{\text {abcd }}$ & $13.65^{\mathrm{abcd}}$ & $0.773^{\mathrm{abc}}$ & $0.754^{\mathrm{ab}}$ & 0.545 & $0.637^{\mathrm{ab}}$ & $0.765^{\mathrm{a}}$ \\
\hline 2 & $14.25^{\mathrm{abcde}}$ & $13.92^{\text {abcde }}$ & $0.794^{\mathrm{abcd}}$ & $0.776^{\mathrm{abc}}$ & 0.557 & $0.658^{a b c}$ & $0.795^{\mathrm{abc}}$ \\
\hline 3 & $13.73^{\mathrm{ab}}$ & $13.4^{\mathrm{ab}}$ & $0.768^{\mathrm{ab}}$ & $0.750^{\mathrm{ab}}$ & 0.588 & $0.658^{\mathrm{abc}}$ & $0.799^{b c}$ \\
\hline 4 & $14.44^{\text {bcde }}$ & $14.03^{\mathrm{bcde}}$ & $0.811^{\mathrm{cd}}$ & $0.788^{b c}$ & 0.607 & $0.678^{a b c}$ & $0.807^{c}$ \\
\hline 5 & $14.38^{\mathrm{abcde}}$ & $14.05^{\mathrm{bcde}}$ & $0.804^{\mathrm{bcd}}$ & $0.785^{b c}$ & 0.599 & $0.685^{\mathrm{abc}}$ & $0.802^{\mathrm{c}}$ \\
\hline 6 & $13.82^{\mathrm{abc}}$ & $13.44^{\mathrm{abc}}$ & $0.762^{\mathrm{a}}$ & $0.742^{\mathrm{a}}$ & 0.565 & $0.614^{\mathrm{a}}$ & $0.763^{\mathrm{a}}$ \\
\hline 7 & $14.20^{\text {abcde }}$ & $13.86^{\text {abcde }}$ & $0.790^{\mathrm{abcd}}$ & $0.771^{\mathrm{abc}}$ & 0.560 & $0.742^{c}$ & $0.768^{\mathrm{ab}}$ \\
\hline 8 & $13.68^{a}$ & $13.32^{\mathrm{a}}$ & $0.762^{\mathrm{a}}$ & $0.743^{\mathrm{a}}$ & 0.563 & $0.696^{\mathrm{abc}}$ & $0.764^{\mathrm{a}}$ \\
\hline 9 & $14.03^{\mathrm{abcd}}$ & $13.64^{\mathrm{abcd}}$ & $0.778^{a b c}$ & $0.756^{\mathrm{ab}}$ & 0.575 & $0.605^{\mathrm{a}}$ & $0.781^{\mathrm{abc}}$ \\
\hline 10 & $14.55^{\mathrm{de}}$ & $14.17^{\mathrm{de}}$ & $0.804^{\mathrm{bcd}}$ & $0.783^{b c}$ & 0.572 & $0.668^{a b c}$ & $0.806^{\mathrm{c}}$ \\
\hline 11 & $14.05^{\mathrm{abcd}}$ & $13.71^{\text {abcde }}$ & $0.770^{\mathrm{ab}}$ & $0.752^{\mathrm{ab}}$ & 0.559 & $0.672^{a b c}$ & $0.767^{\mathrm{ab}}$ \\
\hline 12 & $14.50^{\text {cde }}$ & $14.11^{\text {cde }}$ & $0.803^{b c d}$ & $0.782^{b c}$ & 0.591 & $0.710^{b c}$ & $0.804^{\mathrm{c}}$ \\
\hline 13 & $14.36^{\mathrm{abcde}}$ & $13.96^{\text {abcde }}$ & $0.798^{\mathrm{abcd}}$ & $0.776^{\mathrm{abc}}$ & 0.606 & $0.728^{b c}$ & $0.807^{\mathrm{c}}$ \\
\hline 14 & $14.05^{\mathrm{abcd}}$ & $13.65^{\mathrm{abcd}}$ & $0.782^{\mathrm{abc}}$ & $0.759^{a b c}$ & 0.570 & $0.677^{\mathrm{abc}}$ & $0.780^{\mathrm{abc}}$ \\
\hline 15 & $14.81^{\mathrm{e}}$ & $14.36^{\mathrm{e}}$ & $0.822^{\mathrm{d}}$ & $0.797^{c}$ & 0.597 & $0.742^{\mathrm{c}}$ & $0.811^{\mathrm{c}}$ \\
\hline 16 & $14.40^{\text {bcde }}$ & $13.96^{\text {abcde }}$ & $0.801^{\mathrm{abcd}}$ & $0.777^{\mathrm{abc}}$ & 0.605 & $0.737^{\mathrm{c}}$ & $0.790^{\mathrm{abc}}$ \\
\hline 17 & $14.36^{\text {abcde }}$ & $13.99^{\text {abcde }}$ & $0.807^{\mathrm{bcd}}$ & $0.785^{\mathrm{bc}}$ & 0.572 & $0.717^{\mathrm{bc}}$ & $0.789^{a b c}$ \\
\hline Mean & 14.21 & 13.84 & 0.790 & 0.769 & 0.578 & 0.684 & 0.788 \\
\hline $\mathrm{SEM}^{2}$ & 0.212 & 0.203 & 0.0118 & 0.0113 & 0.0168 & 0.0281 & 0.0101 \\
\hline$P$ & 0.012 & 0.017 & 0.004 & 0.005 & 0.179 & 0.007 & $<0.001$ \\
\hline
\end{tabular}

$710 \quad{ }^{1}$ Each value represents mean of 8 experimental units of 6 birds each.

$711 \quad{ }^{2}$ Standard error of means.

712 Means within a column with no common superscripts differ significantly $(P<0.05)$. 
713 Table 6. The ${ }^{1}$ voluntary feed intake, growth, feed conversion ratio, and ileal digesta

714 viscosity of broilers fed experimental wheat based diets. (Data based on feeding period 715 from day old to 21 days of age).

\begin{tabular}{clllll}
\hline $\begin{array}{c}\text { Wheat } \\
\text { samples }\end{array}$ & FI & WG & FCR & BW & $\begin{array}{l}\text { Ileal } \\
\text { viscosity }\end{array}$ \\
\hline 1 & $42.5^{\mathrm{bc}}$ & $34.9^{\mathrm{c}}$ & 1.213 & $0.773^{\mathrm{c}}$ & 2.63 \\
2 & $37.7^{\mathrm{a}}$ & $30.4^{\mathrm{a}}$ & 1.235 & $0.679^{\mathrm{a}}$ & 2.16 \\
3 & $39.7^{\mathrm{abc}}$ & $33.2^{\mathrm{abc}}$ & 1.211 & $0.738^{\mathrm{abc}}$ & 2.09 \\
4 & $39.4^{\mathrm{abc}}$ & $32.1^{\mathrm{abc}}$ & 1.225 & $0.714^{\mathrm{abc}}$ & 1.65 \\
5 & $42.3^{\mathrm{bc}}$ & $34.4^{\mathrm{c}}$ & 1.224 & $0.763^{\mathrm{c}}$ & 2.01 \\
6 & $38.5^{\mathrm{ab}}$ & $32.0^{\mathrm{abc}}$ & 1.201 & $0.711^{\mathrm{abc}}$ & 2.14 \\
7 & $37.5^{\mathrm{a}}$ & $30.8^{\mathrm{ab}}$ & 1.213 & $0.687^{\mathrm{ab}}$ & 1.97 \\
8 & $43.1^{\mathrm{c}}$ & $34.6^{\mathrm{c}}$ & 1.232 & $0.766^{\mathrm{c}}$ & 1.61 \\
9 & $42.1^{\mathrm{bc}}$ & $33.7^{\mathrm{bc}}$ & 1.243 & $0.748^{\mathrm{bc}}$ & 2.44 \\
10 & $40.4^{\mathrm{abc}}$ & $33.2^{\mathrm{abc}}$ & 1.211 & $0.737^{\mathrm{abc}}$ & 2.93 \\
11 & $41.8^{\mathrm{bc}}$ & $33.5^{\mathrm{bc}}$ & 1.238 & $0.745^{\mathrm{bc}}$ & 2.39 \\
12 & $41.5^{\mathrm{abc}}$ & $34.0^{\mathrm{c}}$ & 1.220 & $0.754^{\mathrm{c}}$ & 2.38 \\
13 & $40.1^{\mathrm{abc}}$ & $32.2^{\mathrm{abc}}$ & 1.237 & $0.716^{\mathrm{abc}}$ & 2.66 \\
14 & $39.9^{\mathrm{abc}}$ & $32.9^{\mathrm{abc}}$ & 1.209 & $0.730^{\mathrm{abc}}$ & 1.75 \\
15 & $41.1^{\mathrm{abc}}$ & $33.5^{\mathrm{abc}}$ & 1.197 & $0.743^{\mathrm{abc}}$ & 1.73 \\
16 & $38.8^{\mathrm{ab}}$ & $32.1^{\mathrm{abc}}$ & 1.210 & $0.713^{\mathrm{abc}}$ & 1.96 \\
17 & $42.2^{\mathrm{bc}}$ & $34.3^{\mathrm{c}}$ & 1.233 & $0.760^{\mathrm{c}}$ & 2.04 \\
Mean & 40.5 & 33.1 & 1.221 & 0.734 & 2.15 \\
SEM & 1.21 & 0.92 & 0.0138 & 0.0194 & 0.282 \\
$P$ & 0.013 & 0.023 & 0.478 & 0.022 & 0.062 \\
\hline
\end{tabular}

$716 \quad{ }^{1}$ Each value represents mean of 8 experimental units of 6 birds each.

$717{ }^{2}$ Standard error of means.

718 Means within a column with no common superscript differ significantly $(P<0.05)$.

719 FI= average daily feed intake (gram/bird/day on dry mater), WG= average daily body weight gain 720 (gram/bird/day), FCR= mortality corrected feed conversion ratio (g/g on dry matter), BW= average final 721 body weight $(\mathrm{kg})$ at $\mathrm{d} 21$, Ileal digesta viscosity at $\mathrm{d} 21$. 
Table 7. Correlation coefficients between broiler growth performance, metabolisable energy, nutrient utilisation and chemical composition and quality characteristics of seventeen wheat samples.

\begin{tabular}{|c|c|c|c|c|c|c|c|c|c|c|c|c|c|c|c|}
\hline & $\mathrm{CP}$ & Fat & Ash & Starch & NSPins & NSPsol & SW & EH & NR & FD & DMR & FI & WG & FCR & AME \\
\hline $\mathrm{CP}$ & 1 & & & & & & & & & & & & & & \\
\hline Fat & -0.314 & 1 & & & & & & & & & & & & & \\
\hline Ash & 0.414 & -0.207 & 1 & & & & & & & & & & & & \\
\hline Starch & -0.227 & 0.048 & 0.045 & 1 & & & & & & & & & & & \\
\hline NSPins & 0.319 & -0.553 & 0.425 & -0.133 & 1 & & & & & & & & & & \\
\hline NSPsol & 0.128 & 0.194 & -0.052 & 0.069 & -0.360 & 1 & & & & & & & & & \\
\hline SW & -0.357 & -0.106 & -0.008 & 0.093 & -0.141 & -0.123 & 1 & & & & & & & & \\
\hline $\mathrm{EH}$ & 0.209 & 0.332 & 0.276 & 0.096 & -0.408 & -0.104 & 0.164 & 1 & & & & & & & \\
\hline NR & -0.292 & 0.031 & -0.737 & 0.146 & -0.350 & 0.126 & -0.156 & -0.232 & 1 & & & & & & \\
\hline FD & -0.511 & 0.282 & -0.345 & 0.038 & -0.289 & -0.152 & -0.039 & -0.254 & 0.450 & 1 & & & & & \\
\hline DMR & -0.386 & 0.222 & -0.744 & 0.080 & -0.383 & 0.484 & -0.121 & -0.346 & 0.773 & 0.348 & 1 & & & & \\
\hline FI & 0.049 & -0.215 & 0.410 & 0.240 & 0.267 & -0.115 & 0.155 & 0.252 & -0.062 & -0.102 & -0.074 & 1 & & & \\
\hline WG & 0.101 & -0.293 & 0.438 & 0.237 & 0.329 & -0.054 & 0.004 & 0.169 & 0.043 & -0.121 & -0.070 & 0.953 & 1 & & \\
\hline FCR & -0.225 & -0.043 & 0.038 & 0.122 & -0.095 & -0.301 & 0.515 & 0.238 & -0.079 & -0.142 & -0.042 & 0.333 & 0.087 & 1 & \\
\hline AME & -0.472 & 0.319 & -0.513 & -0.099 & -0.466 & 0.471 & 0.002 & -0.239 & 0.534 & 0.560 & 0.730 & -0.069 & -0.101 & -0.153 & 1 \\
\hline AMEn & -0.481 & 0.341 & -0.489 & -0.132 & -0.464 & 0.460 & 0.013 & -0.214 & 0.496 & 0.552 & 0.726 & -0.068 & -0.104 & -0.122 & 0.995 \\
\hline
\end{tabular}

CP, NSPins, NSPsol, SW, EH: crude protein, insoluble and soluble non-starch polysaccharides, specific weight and endosperm hardness of seventeen wheat samples. NR, FD, DMR: coefficients of nitrogen retention, fat digestibility and dry matter retention of wheat samples.

FI, WG, FCR: feed intake, weight gain, feed conversion ratio.

729 AME, AMEn: apparent metabolisable energy, $\mathrm{N}$ corrected apparent metabolisable energy of wheat samples. 